\title{
Analysis of Data Consistency Between Land and Buildings Registry and Land and Mortgage Register in order to Create Real Estate Cadastre
}

\section{Introduction}

Both EGiB and KW can be called, according to Bagnicki and Mika [1], information systems. Both examined institutions have long lasting tradition. Their current condition, with regard to the content and quality of databases, is the result of successive technical and legal transformations, caused by the course of history and technical progress [13-15] among others, write about it. The essence of information systems, according to Gaździcki [2: 8-20], is the acquisition, storage, processing and transmission of data representing information.

These systems can be divided into two subgroups:

1) geographic information systems,

2) other information systems.

One can identify many types of terrain information systems, but from the perspective of the creation of real estate cadastre $(\mathrm{KN})$ two of them are crucial: Land and Buildings Registry (EGiB) and Land And Mortgage Registers (KW). The first of them is the land cadastre system; the second is called the legal cadastre. These two systems, as was shown, inter alia, by the researches of $[4,5,18]$ are crucial for the development of the concept of real estate cadastre in Poland.

The aim of this study was the analysis of the Land and Buildings Registry (EGiB) and the Land and Mortgage Registers (KW) in the system approach, in terms of their inter-relationships and dependencies. This issue is important and up to date, mainly in the context of the creation of Real Estate Cadastre (KN) for years in Poland. For the purposes of description and analysis of the flow of spatial and legal information of the currently existing systems EGiB and KW, the most important provisions of the law [16, 17, 20-23], and research conducted on a group of 100 real estates of the selected district were used. Within the meaning of these analyses - the system is

* University of Agriculture in Krakow, Faculty of Environmental Engineering and Land Surveying, Department of Land Surveying, Krakow, Poland 
a collection of elements and relationships between them. The elements of the systems are fragments of the reality; the relationships are interactions between them. The set of relationships is defined in the literature as the structure of the system [12]. When the system consists of such elements, which are systems themselves each of them is called a subsystem, and the system itself is called a superior system. The rest of the reality, not considered in the system and also constituting a specific system, is called the environment of the system. This raises the question, which of the studied systems EGiB and KW in the perspective of combining them into a single system KN should serve as a superior? In order to answer this question, the inter-relationships of the systems were examined and the errors of flow of information between them have been verified and defined.

The basic research problem appeared already at the stage of defining objects of analyzed systems. According to the law [20] - one cadastral plot should correspond to one real estate. This case, unfortunately, is not always the case in practice. The topic is raised, inter alia, in [3: 41-89, 99-132, 168-182, 7, 15]. In fact, there are a lot of cases that the property contains several registry plots. Furthermore - this situation results in most cases in the faulty structure of land $[9,10,19]$. The necessity of the designation of real estate in the KW system through the relevant data obtained from the system $\mathrm{EGiB}$ - for the assignment of property rights means that the KW system is strongly dependent on the EGiB system. The paradox lies in the fact, that $\mathrm{KW}$ system though more important than the EGiB system, is strongly dependent on it and secondary. In contrast, about the system EGiB can be said, that though it plays fully subordinate role in relation to the KW system - it is the primary system. Without EGiB the KW system could not exist, or would exist in a very imperfect form. Designations of real estates, sent to the section I of KW (in the form of description and EGiB maps) are primarily: number, borders and plot area. It often happens that as a designation of the property in the $\mathrm{KW}$ - data from the old cadastral system are used. [6, 8, 11:11-20] write about it, among others. Figure 1 shows a scheme of the flow of information between EGiB and KW systems. Figures 2 and 3 schematically show a hierarchical structure of EGiB and the structure of the example of the Land and Mortgage Register.

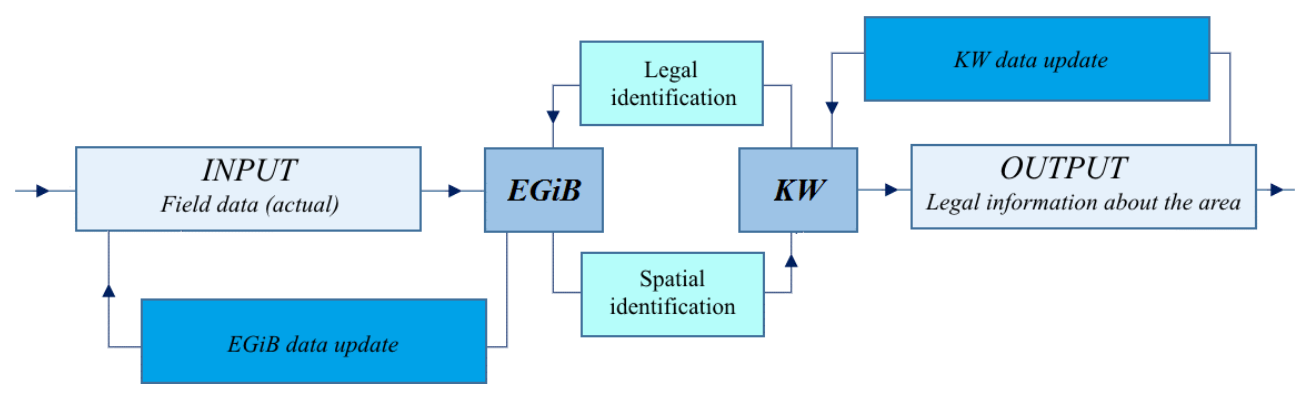

Fig. 1. Scheme of information flow between EGiB and KW systems 


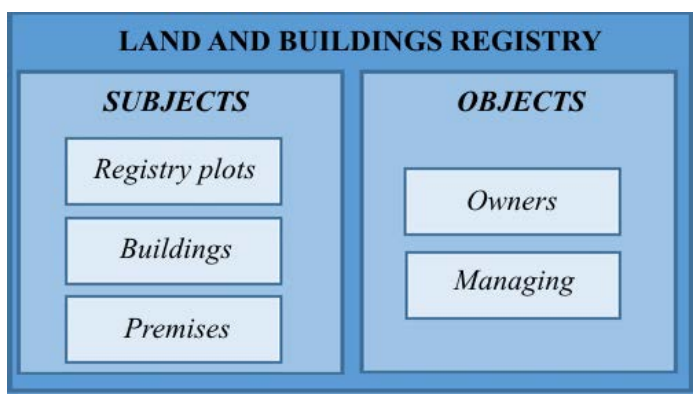

Fig. 2. The hierarchical structure of EGiB

Source: based on [3]

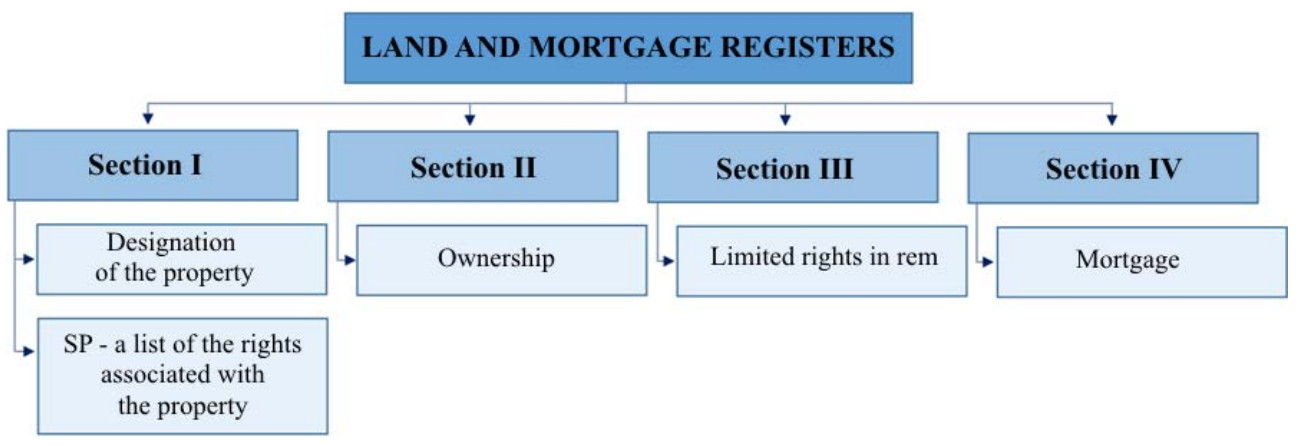

Fig. 3. The structure of land and mortgage registers

\section{Materials and Methods}

Evaluation of the flow of the spatial and legal information between EGiB and the KW systems has been made taking in the account the leading objects in both systems. The plot of land is the leading object in the EGiB system, while the leading object in the KW system is the land property in the meaning of the Land and Mortgage Registers. The detailed scope of the analysis includes both objective and subjective data of a randomly selected group of real estates, registered in both systems. The study area overlaps with the area of influence of the District Court Department of Land and Mortgage Registers in Stalowa Wola and and the District Office in the same town. The extracts from the register of land and premises were verified. A number of features of the properties were selected for comparison, grouped according to the object and subject of the related rights (Tab. 1). The object information referred to the determination of the nature and the scope of assigned rights and verification of personal data of the object entered into the register of land and premises. The subject information was referring to the address data of real estate, the numbers of plots and the agricultural land with an indication of the area and type. Another 
attribute under investigation were the data on the buildings. In the case of the premises real estate the following information on the subject was verified: their location, the number of compartments along with the associated premises and their area and designation of rooms' functions. Besides, the analysis refers to data from the I and II section of land registers and information contained in the extracts from the land and premises registry. Particular attention was paid to the errors of markings between the registers.

Table 1. Types of property which are the subject of elaboration

\begin{tabular}{|c|l|c|}
\hline No. & \multicolumn{1}{|c|}{ Type of property } & Number \\
\hline 1 & Land property & 76 \\
\hline 2 & Land dedicated to perpetual usufruct & 2 \\
\hline 3 & $\begin{array}{l}\text { Land dedicated to perpetual usufruct and building } \\
\text { constituting a separate real estate }\end{array}$ & 6 \\
\hline 4 & Premises constituting a separate real estate & 16 \\
\hline TOTAL: & 100 \\
\hline
\end{tabular}

In a detailed research methodology, for land properties and for land transferred in perpetual usufruct, verification of the rights attached to the property and the number of shares of entities in these rights were taken into account as well as the location of properties, the numbers of registry plots, types of land use divided into classes, areas and buildings. Next, for land transferred in perpetual usufruct and building properties in both of the studied databases compatibility of rights to the property records was verified, and the number of shares of subjects in this right, location of the property, numbers of registry plots, types of land use divided into classes, area and further details of the buildings - registry number of the building, number of floors, the number of premises and the building area. For the last studied group - premises real estate, rights assigned to the property were analyzed, as well as the number of shares of objects in this right, location of property, house and flat number, the utilitarian function, number of rooms, the amount and type of the associated premises, usable area and area of the associated premises.

\section{Results}

Table 2 shows an example of form for testing the compliance of data content in KW and in EGiB for 4 out of 100 analyzed data cases. In a randomly selected sample a significant lack of data compliance can be observed. Figure 4 shows the summary result of studies in the form of a circular diagram. It shows the scale and type of the property designation errors in the surveyed systems. 
Table 2. An example of form for testing the compliance of data content in KW and in EGiB

\begin{tabular}{|c|c|c|c|c|c|}
\hline No. & Compared feature & \multicolumn{2}{|l|}{ EGiB data } & \multicolumn{2}{|c|}{ KW data } \\
\hline \multirow{6}{*}{1} & Type of property & \multicolumn{2}{|c|}{ lack of information } & \multicolumn{2}{|c|}{ land property } \\
\hline & $\begin{array}{l}\text { Type of assigned rights / } \\
\text { number of shares in rights }\end{array}$ & $\begin{array}{l}\text { ownership: } \\
\text { natural person }\end{array}$ & $1 / 1$ & $\begin{array}{l}\text { ownership: } \\
\text { natural person }\end{array}$ & $1 / 1$ \\
\hline & Location & \multicolumn{2}{|c|}{$\begin{array}{l}\text { Voivodship: podkarpackie } \\
\text { District: stalowowolski } \\
\text { Registry unit: Radomyśl } \\
\text { n. Sanem } \\
\text { Precinct: Kępa Rzeczycka }\end{array}$} & \multicolumn{2}{|c|}{$\begin{array}{l}\text { Voivodship: podkarpackie } \\
\text { District: stalowowolski } \\
\text { Commune: Radomyśl } \\
\text { n. Sanem } \\
\text { Location: Kępa Rzeczycka }\end{array}$} \\
\hline & Plot number & \multicolumn{2}{|l|}{77} & \multicolumn{2}{|l|}{77} \\
\hline & $\begin{array}{l}\text { Land use/ } \\
\text { Area [ha] }\end{array}$ & $€$ (meadow) & 0.1400 & $€$ (meadow) & 0.1400 \\
\hline & Buildings & \multicolumn{2}{|l|}{ lack } & \multicolumn{2}{|l|}{ lack } \\
\hline \multirow{22}{*}{2} & Type of property & \multicolumn{2}{|c|}{ lack of information } & \multicolumn{2}{|c|}{ land property } \\
\hline & \multirow{17}{*}{$\begin{array}{l}\text { Type of assigned rights / } \\
\text { number of shares in rights }\end{array}$} & \multicolumn{2}{|c|}{ co-ownership } & \multicolumn{2}{|c|}{ co-ownership } \\
\hline & & natural person & $5 / 56$ & natural person & $5 / 56$ \\
\hline & & $\begin{array}{l}\text { natural person } \\
\text { (other second name }\end{array}$ & $1 / 56$ & $\begin{array}{c}\text { natural person } \\
\text { (other second } \\
\text { name) }\end{array}$ & $1 / 56$ \\
\hline & & natural person & $3 / 56$ & natural person & $3 / 56$ \\
\hline & & natural person & $3 / 56$ & natural person & $3 / 56$ \\
\hline & & natural person & $3 / 56$ & natural person & $3 / 56$ \\
\hline & & natural person & $3 / 56$ & natural person & $3 / 56$ \\
\hline & & married couple & $7 / 56$ & married couple & $7 / 56$ \\
\hline & & married couple & $3 / 56$ & married couple & $3 / 56$ \\
\hline & & married couple & $3 / 56$ & married couple & $3 / 56$ \\
\hline & & married couple & $77 / 448$ & married couple & $77 / 448$ \\
\hline & & married couple & $6 / 56$ & married couple & $6 / 56$ \\
\hline & & married couple & $15 / 896$ & married couple & $15 / 896$ \\
\hline & & married couple & $28 / 448$ & married couple & $28 / 448$ \\
\hline & & married couple & $3 / 56$ & married couple & $3 / 56$ \\
\hline & & married couple & $1 / 56$ & married couple & $1 / 56$ \\
\hline & & married couple & $15 / 896$ & married couple & $15 / 896$ \\
\hline & Location & \multicolumn{2}{|c|}{$\begin{array}{l}\text { Voivodship: podkarpackie } \\
\text { District: stalowowolski } \\
\text { Registry unit: Zaleszany } \\
\text { Precinct: Pilchów }\end{array}$} & \multicolumn{2}{|c|}{$\begin{array}{l}\text { Voivodship: podkarpackie } \\
\text { District: stalowowolski } \\
\text { Commune: Zaleszany } \\
\text { Location: Pilchów }\end{array}$} \\
\hline & Plot number & \multicolumn{2}{|l|}{$606 / 6$} & \multicolumn{2}{|l|}{$606 / 6$} \\
\hline & $\begin{array}{l}\text { Land use/ } \\
\text { Area [ha] }\end{array}$ & $\mathrm{dr}$ (road) & 0.1268 & $\mathrm{dr}$ (road) & 0.1268 \\
\hline & Buildings & \multicolumn{2}{|l|}{ lack } & \multicolumn{2}{|l|}{ lack } \\
\hline
\end{tabular}


Table 2. cont.

\begin{tabular}{|c|c|c|c|c|c|}
\hline No. & Compared feature & \multicolumn{2}{|c|}{ EGiB data } & \multicolumn{2}{|c|}{ KW data } \\
\hline \multirow{8}{*}{3} & Type of property & \multicolumn{2}{|c|}{ lack of information } & \multicolumn{2}{|c|}{ land property } \\
\hline & $\begin{array}{l}\text { Type of assigned rights / } \\
\text { number of shares in rights }\end{array}$ & $\begin{array}{l}\text { ownership: } \\
\text { married couple }\end{array}$ & $1 / 1$ & $\begin{array}{l}\text { ownership: } \\
\text { married couple }\end{array}$ & $1 / 1$ \\
\hline & Location & \multicolumn{2}{|c|}{$\begin{array}{l}\text { Voivodship: podkarpackie } \\
\text { District: stalowowolski } \\
\text { Registry unit: Zaleszany } \\
\text { Precinct: Zbydniów }\end{array}$} & \multicolumn{2}{|c|}{$\begin{array}{l}\text { Voivodship: podkarpackie } \\
\text { District: stalowowolski } \\
\text { Commune: Zaleszany } \\
\text { Location: Zbydniów }\end{array}$} \\
\hline & Plot number & \multicolumn{2}{|l|}{156} & \multicolumn{2}{|l|}{156} \\
\hline & Land use/ & RIVa & 0.2008 & \multirow{3}{*}{$€$} & \multirow{3}{*}{0.2300} \\
\hline & Area [ha] & RV & 0.0334 & & \\
\hline & Location & TOTAL: & 0.2342 & & \\
\hline & Plot number & \multicolumn{2}{|l|}{ lack } & \multicolumn{2}{|l|}{ lack } \\
\hline \multirow{6}{*}{4} & Type of property & \multicolumn{2}{|c|}{ lack of information } & \multicolumn{2}{|c|}{ land property } \\
\hline & $\begin{array}{l}\text { Type of assigned rights / } \\
\text { number of shares in rights }\end{array}$ & $\begin{array}{l}\text { ownership: } \\
\text { married couple }\end{array}$ & $1 / 1$ & $\begin{array}{l}\text { ownership: } \\
\text { married couple }\end{array}$ & $1 / 1$ \\
\hline & Location & \multicolumn{2}{|c|}{$\begin{array}{l}\text { Voivodship: podkarpackie } \\
\text { District: stalowowolski } \\
\text { Registry unit: Zaleszany } \\
\text { Precinct: Zbydniów }\end{array}$} & \multicolumn{2}{|c|}{$\begin{array}{l}\text { Voivodship: podkarpackie } \\
\text { District: stalowowolski } \\
\text { Commune: Zaleszany } \\
\text { Location: Zbydniów }\end{array}$} \\
\hline & Plot number & \multicolumn{2}{|l|}{1754} & \multicolumn{2}{|l|}{1754} \\
\hline & Land use/Area [ha] & LsV & 0.5000 & Ps & 0.5000 \\
\hline & Buildings & \multicolumn{2}{|l|}{ lack } & \multicolumn{2}{|l|}{ lack } \\
\hline
\end{tabular}

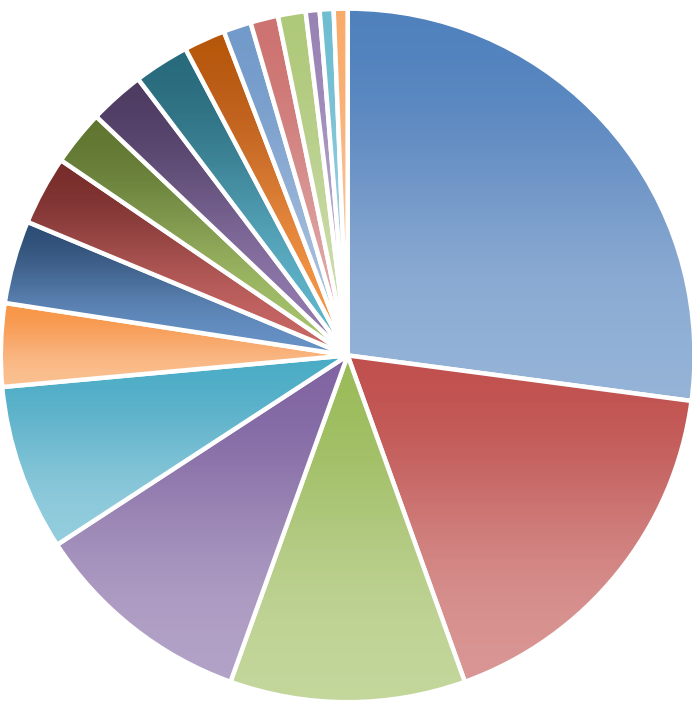

- The lack of parents personal data

- The difference in land use

- The No. of rooms for the premises real estate

- Incorrect designation of location

- The difference of the plot area

- The lack of body representing SP

- The lack of data on buildings

- The lack of building /other building number

- Difference of objects

- The lack of land use designation

- The lack of list of associated premises

- The difference in assigned rights

- The lack of 2nd name of the object

- The lack of plot area

- The lack of area of associated premises

- The difference in objects names

- The lack of plot in EGiB

- The difference in built-up area

Fig. 4. The scale and type of the property designation errors in the surveyed systems 
The most common errors in the KW and EGiB designations detected on the basis of the study are presented in Table 3. The total number of 155 differences between the KW and EGiB were detected for 100 examined land and mortgage registers. Some of them had more than one type of errors which implies the large quantities of defects in the flow of information between of the analyzed systems. Only 23 of the studied documents did not have any errors.

Table 3. List of designations errors in KW and EGiB

\begin{tabular}{|c|c|c|}
\hline No. & The type of errors & $\begin{array}{l}\text { Number of } \\
\text { incidences }\end{array}$ \\
\hline 1 & The lack of parents personal data & 42 \\
\hline 2 & The difference in land use & 27 \\
\hline 3 & The difference in room number for the premises real estate & 17 \\
\hline 4 & Incorrect designation of location & 16 \\
\hline 5 & The difference of plots area & 12 \\
\hline 6 & The lack of body representing SP for the premises real estate & 6 \\
\hline 7 & The lack of data on buildings & 6 \\
\hline 8 & The lack of building number/other building number & 5 \\
\hline 9 & Difference of objects & 4 \\
\hline 10 & The lack of land use designation & 4 \\
\hline 11 & The lack of list of associated premises & 4 \\
\hline 12 & The difference in assigned rights & 3 \\
\hline 13 & The lack of the second object name & 2 \\
\hline 14 & The lack of plot area & 2 \\
\hline 15 & The lack of area of associated premises & 2 \\
\hline 16 & The difference in objects names & 1 \\
\hline 17 & The lack of plot in EGiB & 1 \\
\hline 18 & The difference in built-up area & 1 \\
\hline
\end{tabular}

\section{Conclusion and Discussion}

The problem resulting from the lack of uniformity of the data contained in the $\mathrm{EGiB}$ and $\mathrm{KW}$ systems is unfortunately a common problem and the same time very serious. The only reasonable solution is to find the cause of errors in the designations and to attempt to remove inconsistencies and introduce new, correct records for both registers. One of the reasons of erroneous designations in EGiB and KW may be the incompatibility of the actual status on the ground with the legal status disclosed in the content of KW. This is the case, when the legal status of KW will lose 
actuality, eg. in the case of death of the property owner. This situation can also happen as a result of an incorrect recording made in KW. The situation is complicated by the fact of long waiting times for the creation of KW or updating of its records in the most Courts Divisions of Land and Mortgage Registers. Any delay in the entry of rights related to the property to the content $\mathrm{KW}$ has a negative impact on their reflection in EGiB [4]. It should be noted, that in 2000, only $25-30 \%$ of the property had established KW. At the same time in EGiB existed about 30 million parcels - their legal status, therefore, was documented only by 11 million KW. A similar state of things becomes the cause of the lack of the legal status regulation of real estate, and thus the impossibility of verifying the subject register data [4]. An important aspect is also the fact, that often the basis for entries in section I-O KW are not only the EGiB data, but also other documents. In some regions of Poland the source of data for KW are other cadastral data. The most important factors influencing the non-compliance of the content of both systems is the flawed flow of information between them. Unfortunately, it is anticipated that this condition over time can deteriorate, with the resulting increases of the likelihood of distortion or total loss of the links between the specified objects in both registers [1]. The solution would be to adopt rules, that information about the data in question should reach $\mathrm{KW}$ only from $\mathrm{EGiB}$, while the data of a legal nature in EGiB should came only from KW. To improve the situation, it is also necessary to change regulations so that all the entries in the content of KW should have a constitutive nature warranty principle of public faith should also include the section I-O of KW, the establishment of KW and KW entries must be carried out immediately after the submission of application.

\section{References}

[1] Bagnicki J., Mika M.: Analiza niezgodności danych opisowych działki (nieruchomości) na przykładzie wybranego obrębu ewidencyjnego. Infrastruktura i Ekologia Terenów Wiejskich, nr 2/II 2/II, 2013, pp. 99-109.

[2] Gaździcki J.: Systemy katastralne. Polskie Przedsiębiorstwo Wydawnictw Kartograficznych im. Eugeniusza Romera, Warszawa, Wrocław 1995.

[3] Hycner R.: Podstawy katastru. Uczelniane Wydawnictwa Naukowo-Dydaktyczne AGH, Kraków 2004.

[4] Hycner R., Mika M.: System ksiag wieczystych w Polsce - analiza stanu istniejacego w aspekcie przeptywu informacji o terenie $i$ tworzenia katastru nieruchomości. Geodezja: półrocznik Akademii Górniczo-Hutniczej im. Stanisława Staszica w Krakowie, t. 6, z. 1, 2000, pp. 71-79.

[5] Hycner R., Skotnicki K.: Badania przepływu informacji przestrzennej i prawnej pomiędzy systemem ewidencji gruntów i budynków a systemem ksiag wieczystych. Geodezja: półrocznik Akademii Górniczo-Hutniczej im. Stanisława Staszica w Krakowie, t. 6, z. 2, 2000, pp. 173-185. 
[6] Hanus P., Hycner R., Kwartnik Pruc A.: Analiza terminologiczna wybranych problemów katastru i zagadnień pokrewnych. Cz. 2: Prosto do katastru i mierniczego. Geodeta: Magazyn Geoinformacyjny, nr 11, 2013, pp. 26-34.

[7] Janus J., Mika M., Leń P., Siejka M., Taszakowski J.: A new approach to calculate the land fragmentation indicators taking into account the adjacent plots. Survey Review, July 2016, DOI 10.1080/00396265.2016.1210362.

[8] Kwartnik-Pruc A. (red.), Bacior S., Bieda A., Mika M., Pęska A., Siejka M., Trembecka A., Wróbel A.: Rola danych geodezyjnych w wybranych procesach gospodarki nieruchomościami. Wyższa Szkoła Inżynieryjno-Ekonomiczna, Rzeszów 2015

[9] Len P., Mika M.: Analysis of the flawed spatial structure of land in selected villages of the south-eastern Poland. Geomatics, Landmanagement and Landscape, no. 2, 2016, pp. 107-119.

[10] Leń P., Mika M.: Determination of the urgency of undertaking land consolidation works in the villages of the Stawno municipality. Journal of Ecological Engineering, vol. 17, issue 4, 2016, pp. 163-169.

[11] Malina R., Kowalczyk M.: Geodezja katastralna: procedury geodezyjne i prawne: przykłady operatów. Wydawnictwo Gall, Katowice 2011.

[12] Mika M.: Model systemu katastralnego w jezyku analizy obiektowej OOA. Geomatics and Environmental Engineering, vol. 1, no. 4, 2007, pp. 201-211.

[13] Mika M.: Historia katastru polskiego. Infrastruktura i Ekologia Terenów Wiejskich, nr 6, 2010, pp. 75-85.

[14] Mika M., Kwartnik-Pruc A., Leń P., Bielska A., Oleniacz G., Dawid L., Deska K., Trembecka A.: Wybrane zagadnienia z zakresu kształtowania katastru nieruchomości w Polsce. Współczesne problemy i trendy. Wyd. Uniwersytetu Rolniczego w Krakowie, Kraków 2015.

[15] Mika M., Siejka M.: Wpływ geograficznych i historycznych uwarunkowań na identyfikacje granic nieruchomości na przykładzie katastru austriackiego. Acta Scientiarum Polonorum. Administratio Locorum, t. 11, nr 4, 2012, pp. 65-74.

[16] Rozporzadzenie Ministra Rozwoju Regionalnego i Budownictwa z dnia 29 marca 2001 r. w sprawie ewidencji gruntów i budynków. Dz.U. 2001 nr 38, poz. 454.

[17] Rozporzadzenie Ministra Administracji i Cyfryzacji z dnia 29 listopada 2013 r. zmieniające rozporządzenie w sprawie ewidencji gruntów i budynków. Dz.U. 2013, poz. 1551.

[18] Siejka M., Ślusarski M., Mika M.: Legal and technical aspects of modernization of land and buldings cadastre in selected area. Reaports on Geodesy and Geoinformatics, vol. 99, 2015, pp. 44-53.

[19] Taszakowski J., Janus J., Mika M., Leń P.: Katastralne scalenia gruntów w procesie modernizacji katastru nieruchomości w Polsce. Infrastruktura i Ekologia Terenów Wiejskich, nr II/I, 2016, pp. 375-394.

[20] Ustawa z dnia 6 lipca 1982 r. o ksieggach wieczystych i hipotece. Dz.U. 1982, nr 19, poz. 147. 
[21] Ustawa z dnia 17 maja 1989 r. - Prawo geodezyjne i kartograficzne. Dz.U. 1989, nr 30, poz. 163.

[22] Ustawa z dnia 23 kwietnia 1964 r. - Kodeks cywilny. Consolidated text: Dz.U. 2014, poz. 121.

[23] Ustawa z dnia 7 lipca 1994 r. - Prawo budowlane. Dz.U. 1994, nr 89, poz. 414 with amendments. 